\title{
Enhancing identification accuracy for powdery mildews using previously underexploited DNA loci
}

Article

Accepted Version

Ellingham, O., David, J. and Culham, A. (2019) Enhancing identification accuracy for powdery mildews using previously underexploited DNA loci. Mycologia, 111 (5). pp. 798-812. ISSN 0027-5514 doi:

https://doi.org/10.1080/00275514.2019.1643644 Available at https://centaur.reading.ac.uk/85952/

It is advisable to refer to the publisher's version if you intend to cite from the work. See Guidance on citing.

To link to this article DOI: http://dx.doi.org/10.1080/00275514.2019.1643644

Publisher: Taylor \& Francis

All outputs in CentAUR are protected by Intellectual Property Rights law, including copyright law. Copyright and IPR is retained by the creators or other copyright holders. Terms and conditions for use of this material are defined in the End User Agreement.

www.reading.ac.uk/centaur 
Central Archive at the University of Reading

Reading's research outputs online 
Enhancing identification accuracy for powdery mildews using previously underexploited DNA loci Oliver Ellingham School of Biological Sciences, University of Reading, Whiteknights, Reading, RG6 6AS, UK and Jodrell Laboratory, Royal Botanic Gardens, Kew, Richmond, Surrey, TW9 3AB.

John David RHS Garden Wisley, Woking, Surrey, GU23 6QB, UK.

Alastair Culham School of Biological Sciences, University of Reading, Whiteknights, Reading, RG6 6AS, $U K$.

\section{ABSTRACT}

The ITS DNA marker is routinely used for fungal identification but gives a clear result for only three out of four powdery mildew samples. A search for new markers indicates that some genes offer enhanced identification in comparison with ITS. Others fail due to amplification and sequencing difficulties and lack of informative variability. Powdery mildews (Ascomycota, Erysiphales) are biotrophic, fungal plant pathogens, which commonly occur worldwide on a wide range of host plants. They are unsightly and greatly reduce the vigour of their hosts and have major impacts on crops and other cultivated plants. Species within this order are straightforward to spot, but difficult to identify. A citizen science scheme was run 2013-2016 in the UK to gather a wide array of samples on which identification methods could be developed. Current techniques for identification and phylogenetic reconstruction show scope for improvement. In this paper we review genes used in other fungal groups for discrimination at species level. Working protocols for amplification and sequencing of seven genes (Actin, $\beta$-tubulin, Calmodulin, Chs, EF1- $\alpha, M c m 7$, and Tsr1) are developed with varying success; $M c m 7$ proves to be the most useful at differentiation between closely related, phylogenetically young powdery mildew species for phylogenetic reconstruction when used separately and in tandem with ITS. We therefore propose this as the most appropriate candidate gene to be used commonly in powdery mildew diagnostics alongside the ITS, furthermore this could be transferred to similarly troublesome fungal clades. 
KEY WORDS Erysiphales, powdery mildew, citizen science, survey, BLAST, phylogeny, molecular markers, ITS, Mcm7. 


\section{INTRODUCTION}

Powdery mildews (PMs) are some of the most diverse and frequently encountered plant pathogenic fungi in the world (Braun, 1987). The 872 species described by Braun and Cook (2012) form a characteristic white talcum powder-like coating on the surfaces of approximately 10,000 different host plants (Braun, 1987) including economically important crops and ornamentals. Accurate identification is essential for effective control; however these obligate biotrophs pose problems for taxonomists as many species lack clear morphological characters to distinguish them, are difficult to culture, and therefore require molecular techniques to discriminate between them. Traditional identification methods depend upon a combination of host plant identity and fungal morphology, although more recently sequencing of genomic rDNA regions have come to be used. The internal transcribed spacer (ITS) (Schoch et al., 2012) was proposed as the anchoring barcoding region for fungal identification and has been used extensively within the Erysiphales (Kovács et al., 2011; Wang et al., 2013). Such studies have furthered the efficiency and accuracy of PM species identification, but leave scope for improvement; discrepancies remain in the consistent separation using phylogenetic and barcoding analyses of closely-related, phylogenetically young species.

Fungal phylogenomics has led to an increase in the use of low-copy number protein-coding genes for resolving deep or species-level phylogenies (Aguileta et al., 2008; Schmitt et al., 2009; Curto et al., 2012). These are useful at species level because of their sometimes rapid evolutionary rate (Sang, 2002; Small et al., 2004; Choi et al., 2006). However, given the high evolutionary rate inherent in some low-copy regions, markers may not work consistently among sister lineages because the primer sites may differ. In cases of rapid speciation, DNA may not have diverged sufficiently to resolve a phylogeny using a single locus (Beltrán et al., 2002; Seehausen et al., 2003). This has been shown to be the case in numerous clades (Reeb et al., 2004; Raja et al., 2011; Morgenstern et al., 2012), including the PMs (Khodaparast et al., 2001; Heluta et al., 2010; Kabaktepe et al., 2017). However, multiple independent loci can often provide the necessary variability for reliable species 
identification using phylogenetic analyses and DNA barcoding (Beltrán et al., 2002; Sang, 2002) due to the greater level of sampling of the genome. The process of finding markers that are effective at generating species-level discrimination are essential for developing molecular approaches to identification.

Potentially useful, understudied regions, can be mined from four published genomes; Blumeria graminis (Spanu et al., 2010; Wicker et al., 2013), Erysiphe necator (Jones et al., 2014), and Erysiphe pisi and Golovinomyces orontii (Max Planck Institute for Plant Breeding Research). Through analyses of alignments of the PM genomes alongside closely-related Ascomycota, primers can be developed for exclusive amplification of PMs.

This data mining has been largely driven by phylogenetic reconstruction efforts, initially at familial and generic levels, but now focused on species (Inuma et al., 2007; Takamatsu et al., 2008a; Takamatsu et al., 2008b; Takamatsu, 2013; Meeboon et al., 2015; Meeboon \& Takamatsu, 2015a, b, c). The use of additional DNA regions in tandem with ITS can increase phylogenetic resolution and stability at multiple taxonomic levels. A standard, broadly applicable, PM specific, set of sequence markers would be a valuable resource in constructing robust PM phylogenies using only a few loci (Schmitt et al., 2009) without the expense of whole genome sequencing, while also informing studies of other fungi. A further problem is the risk of contamination from host or hyperparasite DNA, which is normally overcome by growing the required Fungi in single spore culture, however, PM culturing trials have rarely succeeded (Morrison, 1960; Kenyon et al., 1995; Álvarez \& Torés, 1997; Nicot et al., 2002).

Numerous regions have been used routinely to identify species and infer evolutionary relationships within the Ascomycota. A review of literature highlighted genes worthy of detailed investigation in the PMs. This shortlist includes: Actin (McElroy et al., 1990; Reece et al., 1992; Baldauf et al., 2000; Voigt \& Wöstemeyer, 2000; Daniel et al., 2001; Voigt \& Wöstemeyer, 2001; Daniel \& Meyer, 2003; Yun et al., 2003; Opalski et al., 2005; Hunter et al., 2006), ß-tubulin (O' Donnell et al., 1998b; de Jong 
et al., 2001; McKean et al., 2001; Einax \& Voigt, 2003; Juuti et al., 2005), Calmodulin (Stevens, 1983; O’ Donnell et al., 2000; Mulè et al., 2004; Wang \& Zhuang, 2007; Madrid et al., 2009; Romeo et al., 2011; Samson et al., 2014), Chitin synthase (Chs) (Roberts et al., 1986; Kano et al., 1997; Debono \& Gordee, 1994; Zhang et al., 2000; Kong et al., 2012), Elongation factor 1 alpha (EF1-a) (O' Donnell et al., 1998a; Roger et al., 1999; Baldauf et al., 2000; Seifert \& Lévesque, 2004; Kristensen et al., 2005; Hunter et al., 2006; Maphosa et al., 2006; Matheny et al., 2007; Amatulli et al., 2010), Mcm7 (Moir et al., 1982; Kearsey \& Labib, 1998; Aguileta et al., 2008; Schmitt et al., 2009; Leavitt et al., 2011; Raja et al., 2011; Divakar et al., 2012; Morgenstern et al., 2012; Minnis \& Lindner, 2013; Tretter et al., 2013; Tretter et al., 2014; Prieto \& Wedin, 2016), and Tsr1 (Gelperin et al., 2001; Schmitt et al., 2009; Tretter et al., 2013; Sadowska-Deś et al., 2013). In the present study the possibility of developing working molecular markers for these regions for PM samples collected through a citizen science survey in the UK was investigated. The value of resultant data for species identification using phylogenetic reconstruction is explored with reference to the ITS region.

\section{MATERIALS AND METHODS}

Sample collection - The Powdery Mildew Survey-A total of 596 samples were collected from around the UK via the powdery mildew citizen science scheme (article in preparation). Contributors were asked to submit PM samples via the postal service along with GPS data. Any supplied host identifications were checked after receipt and all PM identifications were carried out by the researchers. Fungal packets and extracted DNA were deposited in Reading Herbarium (RNG). Five hundred and seven of these were successfully amplified using previously designed ITS markers PMITS1 and PMITS2 (Cunnington et al., 2003). These acted as reference sequences for later sequencing of novel DNA regions.

Initial species identification. - Putative species identification was achieved using previously established methods: host plants were identified using the Vegetative key to the British Flora (Poland \& Clement, 2009) and confirmed by comparison with standard herbarium specimens at 
RNG; fungi were mounted on slides and imaged using a Leica DM2000 LED with associated Leica Application Suite, and morphological features noted according to Braun and Cook (2012); and rDNA ITS sequence data were analysed using Megablast (Altschul et al., 1990) with a threshold of $99 \%$ similarity indicating allegiance to specific PM species (Tang et al., 2017).

DNA isolation. -DNA was extracted from 0.01-0.02g dry weight of infected leaf material. Leaf material was frozen using liquid nitrogen and ground with two tungsten carbide ball bearings and acid washed silica sand using the Qiagen TissueLyser II. The Qiagen DNeasy Plant Mini Kit protocol was then followed without modification.

Data mining for molecular markers and DNA amplification.-Generic primers listed in SUPPLEMENTARY TABLE 1 were initially trialled with limited success for amplifying PM amplicons. PM genomes (Spanu et al., 2010; Wicker et al., 2013; Jones et al., 2014) were aligned with closely related ascomycetous species of the genes in question (TABLE 1), using MUSCLE (Edgar, 2004) and manually edited such that all bases were in the correct amino acid reading frame, in order to identify the location of the candidate genes and then develop primers to trial in the amplification of accessions. Primers were designed manually with the aid of the web-based software Primer-BLAST (Ye et al., 2012) and Primer3 (Untergasser et al., 2012). The optimal primer-choice conditions were set for a length of approximately 20 bases, annealing temperature $(\mathrm{Tm})$ of $60^{\circ} \mathrm{C}$, and GC content of around 50\%. Default salt concentrations were used in each case. Primer pairs were developed to produce amplicons of 300-1300 bp (depending upon gene) (SUPPLEMENTARY TABLE 2) and ordered from Sigma-Aldrich. Primers shown to have the greatest amplification and sequencing success and therefore deemed the most useful are listed in TABLE 2.

PCR was carried out using the newly designed primers for five individual gene regions. All possible primer combinations resulting in amplicons of greater than $200 \mathrm{bp}$ were trialled; the most successful (success $=$ number of products $\mathrm{x}$ product strength) were further trialled at a gradient of annealing 
temperatures until a single combination was finalised for each candidate gene. $25 \mu$ I PCR mixes comprised of $12.5 \mu \mathrm{l}$ BioMix ${ }^{\mathrm{TM}}$ Red (Bioline), $0.75 \mu \mathrm{l} \mathrm{BSA}\left(10 \mathrm{ng} \mu^{-1}\right), 0.875 \mu \mathrm{l}$ of each primer at 10 $\mu \mathrm{M}, 9 \mu \mathrm{l}$ RO water, and $1 \mu \mathrm{l}$ of sample DNA at concentrations of 10-50 $\mathrm{ng} \mu^{-1}$. Cycling parameters were adapted from Amrani and Corio-Costet (2006) with an initial denaturation step of $95^{\circ} \mathrm{C}$ for five minutes, followed by 37 cycles of denaturation at $95^{\circ} \mathrm{C}$ for 30 seconds, annealing for one minute at varying temperatures for different genes, and elongation at $72{ }^{\circ} \mathrm{C}$ for one and a half minutes and a final elongation at $72{ }^{\circ} \mathrm{C}$ for five minutes. Single amplicons of more than $10 \mathrm{ng}$ per band were then sent to Source BioScience in 2014 and 2015, and GATC in Germany in 2016 for sequencing. Complementary forward and reverse sequences generated in this study were assembled and manually edited using SeqMan Pro software (DNASTAR, Madison, WI, USA) and deposited in GenBank. Reducing the degeneracy and length of the most successful primers was trialled for greater accuracy in amplification and sequencing but rarely improved success.

Phylogenetic analyses. - Alignments of resultant sequence data were performed using MUSCLE (Edgar, 2004) before a manual edit. Accessions within alignments of ITS, Actin, $\beta$-tubulin, Mcm7, and Tsr1 were reduced and trimmed as a result of poor sequence quality and short reads and were concatenated in 26 possible combinations using MESQUITE (Maddison \& Maddison, 2017). Alignment and tree files were deposited in TREeBASE (TABLE 3).

The optimal nucleotide substitution model was selected for each alignment based on the AIC criterion (Akaike, 1974) using PAUP (Swofford, 2003) and MRMODELBLOCK commands generated by MRMOdeLTEST (Nylander, 2004). Bayesian inference (BI) was performed in MRBAYES 3.1.2 (Ronquist \& Huelsenbeck, 2003). Combined analyses were run using partitioned models and therefore included optimal nucleotide substitution models for each individual gene alignment. Stationarity was established using a plot of $-\ln$, a $25 \%$ burn-in was used and all trees were rooted with Blumeria graminis ("5_86_Blumeria_graminis_ex_Poa_trivialis") in order to make topologies comparable. All other variables followed default settings of MrBayes. Parameter states and trees were stored every 
10,000 generations to avoid autocorrelation. To ensure convergence was reached, the average standard deviation of split frequencies was monitored to ensure that it fell below 0.03 , and trace files of all parameters were examined using Tracer v1.6 (Rambaut et al., 2015) to ensure proper mixing had happened. Consensus of resultant trees was built and visualised using BAYESTREES 1.3 (http://www.evolution.reading.ac.uk/BayesTrees.html).

Phylogenies inferred for each combination of regions were compared with the total evidence tree (TET) and relative consensus fork indexes (RCFI) were estimated to give the proportion of nodes shared among the trees (Colless, 1980) (TABLE 3).

\section{RESULTS}

Candidate regions. -

Actin. ActF1 and ActR3 showed the greatest success in amplification and sequencing. Degeneracy in these primers was reduced based on initial sequence data, and primers ActF1a and ActR3b were developed and used in all future amplifications to amplify a product of $500 \mathrm{bp}$ with an annealing temperature of $60^{\circ} \mathrm{C}$. Sequences were contributed to GenBank (Accession numbers KY786551 - KY786689).

6-tubulin. BTF5 and BTR7 showed the greatest success in amplification and sequencing. Degeneracy in these primers was reduced based on initial sequence data and primers BTF5b and BTR7a were developed. This was used in all future amplifications to amplify a product of $800 \mathrm{bp}$ with an annealing temperature of $55^{\circ} \mathrm{C}$. Sequences were contributed to GenBank (Accession numbers KY786690 - KY786781).

Calmodulin. The Calmodulin region did not show sufficient variability from closely related ascomycete fungi for development of PM specific primers. 
Chitin synthase. The Chs region did not show sufficient variability from closely related ascomycete fungi for development of PM specific primers.

EF1- $\alpha$. All primer combinations resulted in amplification of multiple products. Extension and annealing temperatures and concentrations of primer, DNA and magnesium were therefore explored. However, no combination was shown to consistently produce a single product and the region was explored no further.

Mcm7. Primer combination Mcm7F2 and Mcm7R8 initially showed the greatest success in amplification and sequencing. Degeneracy in these primers was reduced based on initial sequence data and primers but application of new markers produced sequences of lesser quality. Mcm7F2 and Mcm7R8 were therefore used in all future amplifications to amplify a product of $550 \mathrm{bp}$ with an annealing temperature of $54^{\circ} \mathrm{C}$. Sequences were contributed to GenBank (Accession numbers KY786340 - KY786476).

Tsr1. Primer combination Tsr1F1 and Tsr1R6 initially showed the greatest success in amplification and sequencing. Degeneracy in these primers was reduced based on initial sequence data and primers but application of new markers produced sequences of lesser quality. Tsr1F1 and Tsr1R6 were therefore used in all future amplifications to amplify a product of $1150 \mathrm{bp}$ with an annealing temperature of $52{ }^{\circ} \mathrm{C}$. Sequences were contributed to GenBank (Accession numbers KY786477 - KY786550).

Species identification and sample selection, amplification and sequencing. - Morphological examinations of 596 samples enabled identification to PM genus $80 \%$ of the time and to PM species $65 \%$ of the time. Various subsets of all 596 accessions were successfully amplified and sequenced for each candidate gene (TABLE 4). As expected, NCBI BLAST of ITS sequences enabled identification to genera, but less often to species (TABLE 5). For candidate genes this resource was of little use due to the previous lack of existing sequence data (TABLE 5). 
Phylogenetic analyses. - Phylogenies constructed from individual regions enabled evaluation of the relative accuracy of each region when compared to the most commonly used region, the ITS (FIG 1), as well as an ideal total evidence tree. RCFIs displayed in TABLE 3 enable comparison and highlight the sub-optimal Actin gene $(\mathrm{RCFI}=0.684)$, the $\beta$-tubulin $(\mathrm{RCFI}=0.874)$ and $T s r 1(\mathrm{RCFI}=0.857)$ genes performing similarly to the ITS $(\mathrm{RCFI}=0.879)$, and the $\mathrm{Mcm} 7$ gene reconstructing a close to optimal tree $(\mathrm{RCFI}=0.974)$. The most informative phylogenies are included (FIG 2, FIG 3, and FIG 4).

The 495 bp alignment of 151 Mcm7 PM accessions (FIG 3) had strong support across all clades, however, relationships within Golovinomyceteae show Neoerysiphe to be sister to Erysiphe, therefore indicating that Golovinomyceteae might be a paraphyletic tribe as currently defined.

The 1315 bp alignment of 102 accessions of the ITS and Mcm7 regions combined has RCFI of 0.972 and high PP support for each tribe and genus (FIG 4). RCFI reaches 1 when combining the four regions of ITS, Mcm7, $\beta$-tubulin, and Tsr1 and ITS, Mcm7, $\beta$-tubulin, and Actin as well as when all five regions were combined (TABLE 3).

\section{DISCUSSION}

Morphological analyses of PM species (Braun \& Cook, 2012) enable correct identification much of the time but require specialist knowledge, access to a high quality microscope, and visual discrimination between microstructures. Complementing morphology with sequencing of rDNA ITS (White et al., 1990; Takamatsu et al., 1998; Tang et al., 2017) has led to improvements in accuracy and efficiency of species identification in the PMs, as well as other Fungi. The abundance, diversity, and quality of PM accessions and ITS sequence data in the current study proved sufficient for testing established PM identification techniques; enabling a high proportion (c. $80 \%$ ) of species to be discriminated. However, many accessions such as those on Heuchera cultivars (Ellingham et al., 2016) yielded ambiguous results using NCBI GenBank BLAST, either due to a lack of relevant ITS data or a lack of variability in deposited ITS data, as well as the presence of misidentified accessions 
(Kovács et al., 2011). ITS has regularly proven to be insufficient for PM species discrimination (Meeboon et al., 2015; Takamatsu et al., 2015; Fonseca et al., 2017) and alternative housekeeping genes have proven to be of varying use for solving this issue (Vela-Corcía et al., 2014; Pirondi et al., 2015).

This was also the case for gene regions tested in the current study to assess their efficacy for species recognition: Calmodulin and Chs alignments lacking priming sites for exclusive amplification of PMs from environmental samples; developed EF1- $\alpha$ primers lacking specificity to PMs; Actin sequences proving to be too variable; only the $\beta$-tubulin, $M c m 7$, and Tsr1 genes showing promise.

Amplification, sequencing, and species discrimination success varied greatly across genes, perhaps due to low quantity and quality of environmental PM DNA. Those which were unsuccessful were characterised by weak reads, resulting in little or no sequence data, or messy reads, potentially contaminated with more than one PM species or with mycoparasitic fungi (Pintye et al., 2015; Topalidou \& Shaw, 2016) and other phylloplane community members (Berendsen et al., 2012; Topalidou, 2014; Franco et al., 2017). Amplification of multiple products in certain accessions was also evident and may indicate that the primer combination is not $100 \%$ specific to PMs; amplifying mycoparasitic fungi as well as the targeted PM. It is also possible that more than one PM species was present in the accession as in certain cases DNA sequences of different genes returned disparate species identifications. These were taken particularly seriously in cases of disparity between $\mathrm{Mcm} 7$ and ITS because they may signal the presence of more than one PM species on the host plant (Cook et al., 2006).

Success in amplification and sequencing of specific PM genes enabled analytical techniques to be evaluated. GenBank MegaBLAST was of little use owing to the dearth of sequence data. This is unsurprising due to the novelty of the genes investigated. However, BLAST within the local dataset (those generated in the current study) proved intraspecific accessions to return highly similar matches within the $\beta$-tubulin, $M c m 7$, and Tsr1 regions. 
Bayesian analyses of the datasets in TABLE 3 resolved numerous monophyletic groupings of distinct taxa. However, while analyses based on $\beta$-tubulin, as well as Tsr1, did produce phylogenies of similar resolution to that of ITS, $M c m 7$ proved superior to each: resolving $97 \%$ of all accessions. The utility of each novel gene has varied across previous studies. The Actin gene in particular has received both positive (Baldauf et al., 2000; Voigt \& Wöstemeyer, 2000; Daniel et al., 2001; Voigt \& Wöstemeyer, 2001; Daniel \& Meyer, 2003) and negative (Weiland \& Sundsbak, 2000; Hunter et al., 2006) reviews. In contrast, the few studies to have used Tsr1 have been mostly positive (Schmitt et al., 2009; Sadowska-Deś et al., 2013; Tretter et al., 2013), however, as in the present study, it was not considered to offer sufficient resolution in the study of Morgenstern et al. (2012). $\beta$-tubulin has regularly emerged as a strong candidate for complementing the ITS in fungal clades including but not limited to Neofabraea species causing tree cankers and bull's eye rot of apple (de Jong et al., 2001), and the Gibberella fujikuroi (Fusarium) species complex (O' Donnell et al., 1998b). Its utility has also been shown in population genetics studies of PMs (Cunnington et al., 2003; Inuma et al., 2007; Brewer \& Milgroom, 2010; Troch et al., 2014; Vela-Corcía et al., 2014). These concur with the current study. Mcm7 proved consistently to enable a high-level of resolution across various fungal clades (Aguileta et al., 2008; Schmitt et al., 2009; Leavitt et al., 2011; Raja et al., 2011; Divakar et al., 2012; Morgenstern et al., 2012; Tretter et al., 2013; Tretter et al., 2014; Prieto \& Wedin, 2016).

Phylogenetic analyses of candidate genes have shown the utility of each; and proved the great potential of $\mathrm{Mcm} 7$ for improving PM diagnostics. The region should be adopted to aid future identification of PM species. Improved efficacy and accuracy of diagnostically useful molecular markers of plant pathogens could be paired with new technologies such as lateral flow microarrays (Carter \& Cary, 2007) or direct PCR (Werle et al., 1994) and on-site sequencing using nanopore technologies such as the MinION (Eisenstein, 2012; Mikheyev \& Tin, 2014; Mitsuhashi et al., 2017). These could offer fast and efficient assays for disease identification for plant health practitioners. Mcm7 must now be tested with broader sampling of PMs from undersampled geographic regions 
and genera. The candidate $\mathrm{Mcm} 7$ primers could be adapted further to improve amplification for specific genera.

The ITS region has historically underpinned fungal diagnostics and, due to the large amount of ITS sequence data already deposited in online sequence databases, is likely to continue to do so. The $\beta$ tubulin region can offer additional diagnostic utility to the PM identification process; serving as an 'identifier' complementing ITS as the 'anchor' region. The $\mathrm{Mcm} 7$ region offers greater promise still and would be an ideal candidate to replace ITS for PMs and potentially all Fungi. However, the existing weight of ITS data means it remains the most widely sequenced identifier of PMs and other fungal clades.

While much work remains, the results obtained in the current study have confirmed: (i) the promise of underexploited markers at complementing existing gene regions in species level discrimination; and (ii) the potential of new techniques to develop rapid diagnostic methods for PMs, and other plant pathogenic fungi.

Consistently rapid and accurate PM identification could benefit researchers and practitioners in this field: (i) to limit the spread of plant pathogenic fungi and minimise the occurrence of devastating disease outbreaks on monoclonal crops and other cultivated plants (Jørgensen, 1992; Frye \& Innes, 1998; Liu et al., 1999); (ii) contribute to more effective chemical (Horst et al., 1992; Faoro et al., 2008) and cultural (Xiao et al., 2001) control, influenced by pathogen species or races; (iii) contribute to breeding programmes aimed at developing disease resistant plants; and (iv) determine whether a pathogen is native or introduced.

\section{LITERATURE CITED}

Aguileta, G, Marthey, S, Chiapello, H, Lebrun, M-H, Rodolphe, F, Fournier, E, Gendrault-Jacquemard, A, and Giraud, T. 2008. Assessing the performance of single-copy genes for recovering robust phylogenies. Systematic biology 57: 613-627. 
Akaike, H. 1974. A new look at the statistical model identification. IEEE transactions on automatic control 19: 716-723.

Altschul, SF, Gish, W, Miller, W, Myers, EW, and Lipman, DJ. 1990. Basic local alignment search tool. Journal of molecular biology 215: 403-410.

Álvarez, B, and Torés, A. 1997. Cultivo in vitro de Sphaerotheca fuliginea (Schlecht. ex Fr.), efecto de diferentes fuentes de carbono sobre su desarrollo. Boletín de sanidad vegetal Plagas 23: 283-288. Amatulli, MT, Spadaro, D, Gullino, ML, and Garibaldi, A. 2010. Molecular identification of Fusarium spp. associated with bakanae disease of rice in Italy and assessment of their pathogenicity. Plant Pathology 59: 839-844.

Amrani, L, and Corio-Costet, MF. 2006. A single nucleotide polymorphism in the $\beta$-tubulin gene distinguishing two genotypes of Erysiphe necator expressing different symptoms on grapevine. Plant Pathology 55: 505-512.

Baldauf, SL, Roger, A, Wenk-Siefert, I, and Doolittle, WF. 2000. A kingdom-level phylogeny of eukaryotes based on combined protein data. Science 290: 972-977.

Beltrán, M, Jiggins, CD, Bull, V, Linares, M, Mallet, J, McMillan, WO, and Bermingham, E. 2002. Phylogenetic discordance at the species boundary: comparative gene genealogies among rapidly radiating Heliconius butterflies. Molecular Biology and Evolution 19: 2176-2190.

Berendsen, RL, Pieterse, CM, and Bakker, PA. 2012. The rhizosphere microbiome and plant health. Trends in Plant Science 17: 478-486.

Braun, U. 1987. A monograph of the Erysiphales (powdery mildews). Beihefte zur Nova Hedwigia.

Braun, U, and Cook, RT. 2012. Taxonomic manual of the Erysiphales (powdery mildews). CBS-KNAW Fungal Biodiversity Centre. 
Brewer, MT, and Milgroom, MG. 2010. Phylogeography and population structure of the grape powdery mildew fungus, Erysiphe necator, from diverse Vitis species. BMC Evol Biol 10: 268.

Carter, DJ, and Cary, RB. 2007. Lateral flow microarrays: a novel platform for rapid nucleic acid detection based on miniaturized lateral flow chromatography. Nucleic acids research 35: e74.

Choi, H-K, Luckow, MA, Doyle, J, and Cook, DR. 2006. Development of nuclear gene-derived molecular markers linked to legume genetic maps. Molecular Genetics and Genomics 276: 56-70.

Colless, D. 1980. Congruence between morphometric and allozyme data for Menidia species: a reappraisal. Systematic Zoology 29: 288-299.

Cook, RTA, Henricot, B, Henrici, A, and Beales, P. 2006. Morphological and phylogenetic comparisons amongst powdery mildews on Catalpa in the UK. Mycological Research 110: 672-685.

Cunnington, JH, Takamatsu, S, Lawrie, AC, and Pascoe, IG. 2003. Molecular identification of anamorphic powdery mildews (Erysiphales). Australasian Plant Pathology 32: 421-428.

Curto, MA, Puppo, P, Ferreira, D, Nogueira, M, and Meimberg, H. 2012. Development of phylogenetic markers from single-copy nuclear genes for multi locus, species level analyses in the mint family (Lamiaceae). Mol Phylogenet Evol 63: 758-767.

Daniel, H-M, and Meyer, W. 2003. Evaluation of ribosomal RNA and actin gene sequences for the identification of ascomycetous yeasts. International journal of food microbiology 86: 61-78.

Daniel, H-M, Sorrell, TC, and Meyer, W. 2001. Partial sequence analysis of the actin gene and its potential for studying the phylogeny of Candida species and their teleomorphs. International Journal of Systematic and Evolutionary Microbiology 51: 1593-1606.

de Jong, SN, Lévesque, CA, Verkley, GJ, Abeln, EC, Rahe, JE, and Braun, PG. 2001. Phylogenetic relationships among Neofabraea species causing tree cankers and bull's-eye rot of apple based on 
DNA sequencing of ITS nuclear rDNA, mitochondrial rDNA, and the $\beta$-tubulin gene. Mycological Research 105: 658-669.

Debono, M, and Gordee, RS. 1994. Antibiotics that inhibit fungal cell wall development. Annual Reviews in Microbiology 48: 471-497.

Divakar, PK, Del-Prado, R, Lumbsch, HT, Wedin, M, Esslinger, TL, Leavitt, SD, and Crespo, A. 2012. Diversification of the newly recognized lichen-forming fungal lineage Montanelia (Parmeliaceae, Ascomycota) and its relation to key geological and climatic events. American Journal of Botany 99: 2014-2026.

Edgar, RC. 2004. MUSCLE: multiple sequence alignment with high accuracy and high throughput. Nucleic acids research 32: 1792-1797.

Einax, E, and Voigt, K. 2003. Oligonucleotide primers for the universal amplification of $\beta$-tubulin genes facilitate phylogenetic analyses in the regnum Fungi. Organisms Diversity \& Evolution 3: 185194.

Eisenstein, M. 2012. Oxford Nanopore announcement sets sequencing sector abuzz. Nature Research.

Ellingham, O, Denton, G, Denton, J, and Robinson, R. 2016. First report of Podosphaera macrospora on Heuchera in the United Kingdom. New Disease Reports 33.

Ellingham, O. 2017. Increasing accuracy of powdery mildew (Ascomycota, Erysiphales) identification using previously untapped DNA regions. Doctoral dissertation, University of Reading.

Faoro, F, Maffi, D, Cantu, D, and Iriti, M. 2008. Chemical-induced resistance against powdery mildew in barley: the effects of chitosan and benzothiadiazole. Biocontrol 53: 387-401.

Fonseca, NR, Guimarães, LM, Pires, RP, Klopfenstein, NB, and Alfenas, AC. 2017. Eucalypt powdery mildew caused by Podosphaera pannosa in Brazil. Tropical Plant Pathology: 1-12. 
Franco, FP, Moura, DS, Vivanco, JM, and Silva-Filho, MC. 2017. Plant-insect-pathogen interactions: a naturally complex ménage à trois. Current opinion in microbiology 37: 54-60.

Frye, CA, and Innes, RW. 1998. An Arabidopsis mutant with enhanced resistance to powdery mildew. The Plant Cell 10: 947-956.

Gelperin, D, Horton, L, Beckman, J, Hensold, J, and Lemmon, SK. 2001. Bms1p, a novel GTP-binding protein, and the related Tsr1p are required for distinct steps of $40 \mathrm{~S}$ ribosome biogenesis in yeast. Rna 7: 1268-1283.

Heluta, V, Takamatsu, S, Harada, M, and Voytyuk, S. 2010. Molecular phylogeny and taxonomy of Eurasian Neoerysiphe species infecting Asteraceae and Geranium. Persoonia 24: 81-92.

Horst, R, Kawamoto, S, and Porter, L. 1992. Effect of sodium bicarbonate and oils on the control of powdery mildew and black spot of roses. Plant Disease 76: 247-251.

Hunter, GC, Wingfield, BD, Crous, PW, and Wingfield, MJ. 2006. A multi-gene phylogeny for species of Mycosphaerella occurring on Eucalyptus leaves. Studies in Mycology 55: 147-161.

Inuma, T, Khodaparast, SA, and Takamatsu, S. 2007. Multilocus phylogenetic analyses within Blumeria graminis, a powdery mildew fungus of cereals. Mol Phylogenet Evol 44: 741-751. Jones, L, Riaz, S, Morales-Cruz, A, Amrine, KC, McGuire, B, Gubler, WD, Walker, MA, and Cantu, D. 2014. Adaptive genomic structural variation in the grape powdery mildew pathogen, Erysiphe necator. Bmc Genomics 15: 1081.

Jørgensen, JH. 1992. Discovery, characterization and exploitation of Mlo powdery mildew resistance in barley. In Breeding for disease resistance, Springer: 141-152.

Juuti, JT, Jokela, S, Tarkka, MT, Paulin, L, and Lahdensalo, J. 2005. Two phylogenetically highly distinct $\beta$-tubulin genes of the basidiomycete Suillus bovinus. Current genetics 47: 253-263. 
Kabaktepe, S, Akata, I, Siahaan, SAS, Takamatsu, S, and Braun, U. 2017. Powdery mildews

(Ascomycota, Erysiphales) on Fontanesia phillyreoides and Jasminum fruticans in Turkey. Mycoscience 58: 30-34.

Kano, R, Nakamura, Y, Watari, T, Watanabe, S, Takahashi, H, Tsujimoto, H, and Hasegawa, A. 1997. Phylogenetic analysis of 8 dermatophyte species using chitin synthase 1 gene sequences. Mycoses 40: 411-414.

Kearsey, SE, and Labib, K. 1998. MCM proteins: evolution, properties, and role in DNA replication. Biochimica et Biophysica Acta (BBA)-Gene Structure and Expression 1398: 113-136.

Kenyon, DM, Dixon, GR, and Helfer, S. 1995. Culture in-vitro of Rhododendron and Erysiphe sp. Plant Pathology 44: 350-354.

Khodaparast, SA, Takamatsu, S, and Hedjaroude, G-A. 2001. Phylogenetic structure of the genus Leveillula (Erysiphales: Erysiphaceae) inferred from the nucleotide sequences of the rDNA ITS region with special reference to the L. taurica species complex. Mycological Research 105: 909-918.

Kimura, M. 1980. A simple method for estimating evolutionary rates of base substitutions through comparative studies of nucleotide sequences. J Mol Evol 16: 111-120.

Kong, L-A, Yang, J, Li, G-T, Qi, L-L, Zhang, Y-J, Wang, C-F, Zhao, W-S, Xu, J-R, and Peng, Y-L. 2012. Different chitin synthase genes are required for various developmental and plant infection processes in the rice blast fungus Magnaporthe oryzae. PLoS Pathog 8: e1002526.

Kovács, GM, Jankovics, T, and Kiss, L. 2011. Variation in the nrDNA ITS sequences of some powdery mildew species: do routine molecular identification procedures hide valuable information? European Journal of Plant Pathology 131: 135-141. 
Kristensen, R, Torp, M, Kosiak, B, and Holst-Jensen, A. 2005. Phylogeny and toxigenic potential is correlated in Fusarium species as revealed by partial translation elongation factor 1 alpha gene sequences. Mycological Research 109: 173-186.

Leavitt, SD, Johnson, L, and Clair, LLS. 2011. Species delimitation and evolution in morphologically and chemically diverse communities of the lichen-forming genus Xanthoparmelia (Parmeliaceae, Ascomycota) in western North America. American Journal of Botany 98: 175-188.

Liu, Z, Sun, Q, Ni, Z, Yang, T, and McIntosh, R. 1999. Development of SCAR markers linked to the Pm21 gene conferring resistance to powdery mildew in common wheat. Plant breeding 118: 215219.

Maddison, WP, and Maddison, DR. 2017. Mesquite: a modular system for evolutionary analysis.

Madrid, H, Cano, J, Gené, J, Bonifaz, A, Toriello, C, and Guarro, J. 2009. Sporothrix globosa, a pathogenic fungus with widespread geographical distribution. Revista iberoamericana de micologia 26: $218-222$.

Maphosa, L, Wingfield, B, Coetzee, M, Mwenje, E, and Wingfield, M. 2006. Phylogenetic relationships among Armillaria species inferred from partial elongation factor 1-alpha DNA sequence data. Australasian Plant Pathology 35: 513-520.

Matheny, PB, Wang, Z, Binder, M, Curtis, JM, Lim, YW, Nilsson, RH, Hughes, KW, Hofstetter, V, Ammirati, JF, and Schoch, CL. 2007. Contributions of rpb2 and tef1 to the phylogeny of mushrooms and allies (Basidiomycota, Fungi). Mol Phylogenet Evol 43: 430-451.

Max Planck Institute for Plant Breeding Research. Powdery Mildew Genome Project. http://www.mpipz.mpg.de/powdery_mildew_project_description.

McElroy, D, Zhang, W, Cao, J, and Wu, R. 1990. Isolation of an efficient actin promoter for use in rice transformation. The Plant Cell Online 2: 163-171. 
McKean, PG, Vaughan, S, and Gull, K. 2001. The extended tubulin superfamily. Journal of Cell Science 114: $2723-2733$.

Meeboon, J, Siahaan, SAS, and Takamatsu, S. 2015. Notes on powdery mildews (Erysiphales) in Japan: IV. Phyllactinia, Parauncinula and Sawadaea. Mycoscience 56: 590-596.

Meeboon, J, and Takamatsu, S. 2015a. Notes on powdery mildews (Erysiphales) in Japan: I. Erysiphe sect. Erysiphe. Mycoscience 56: 257-266.

Meeboon, J, and Takamatsu, S. 2015b. Notes on powdery mildews (Erysiphales) in Japan: II. Erysiphe sect. Microsphaera. Mycoscience 56: 230-236.

Meeboon, J, and Takamatsu, S. 2015c. Notes on powdery mildews (Erysiphales) in Japan: III. Golovinomyces and Podosphaera. Mycoscience 56: 243-251.

Meier, R, Shiyang, K, Vaidya, G, and Ng, PK. 2006. DNA barcoding and taxonomy in Diptera: a tale of high intraspecific variability and low identification success. Systematic biology 55: 715-728.

Mikheyev, AS, and Tin, MM. 2014. A first look at the Oxford Nanopore MinION sequencer. Molecular Ecology Resources 14: 1097-1102.

Minnis, AM, and Lindner, DL. 2013. Phylogenetic evaluation of Geomyces and allies reveals no close relatives of Pseudogymnoascus destructans, comb. nov., in bat hibernacula of eastern North America. Fungal Biology 117: 638-649.

Mitsuhashi, S, Kryukov, K, Nakagawa, S, Takeuchi, JS, Shiraishi, Y, Asano, K, and Imanishi, T. 2017. A portable system for metagenomic analyses using nanopore-based sequencer and laptop computers can realize rapid on-site determination of bacterial compositions. BioRxiv: 101865.

Moir, D, Stewart, SE, Osmond, BC, and Botstein, D. 1982. Cold-sensitive cell-division-cycle mutants of yeast: isolation, properties, and pseudoreversion studies. Genetics 100: 547-563. 
Morgenstern, I, Powlowski, J, Ishmael, N, Darmond, C, Marqueteau, S, Moisan, M-C, Quenneville, G, and Tsang, A. 2012. A molecular phylogeny of thermophilic fungi. Fungal Biology 116: 489-502.

Morrison, RM. 1960. Studies of clonal isolates of Erysiphe cichoracearum on leaf disk culture. Mycologia 52: 388-393.

Mulè, G, Susca, A, Stea, G, and Moretti, A. 2004. Specific detection of the toxigenic species Fusarium proliferatum and F. oxysporum from asparagus plants using primers based on calmodulin gene sequences. FEMS Microbiology Letters 230: 235-240.

Nicot, P, Bardin, M, Dik, A, Bélanger, R, Bushnell, W, and Carver, T. 2002. Basic methods for epidemiological studies of powdery mildews: culture and preservation of isolates, production and delivery of inoculum, and disease assessment. The powdery mildews: a comprehensive treatise: 8399.

Nylander, J. 2004. MrModeltest, version 2. Evolutionary Biology Centre, Uppsala University, Uppsala, Sweden.

O' Donnell, K, Cigelnik, E, and Casper, H. 1998a. Molecular Phylogenetic, Morphological, and Mycotoxin Data Support Reidentification of the Quorn Mycoprotein Fungus as Fusarium venenatum. Fungal Genetics and Biology 23: 57-67.

O' Donnell, K, Cigelnik, E, and Nirenberg, HI. 1998b. Molecular systematics and phylogeography of the Gibberella fujikuroi species complex. Mycologia: 465-493.

O’ Donnell, K, Nirenberg, HI, Aoki, T, and Cigelnik, E. 2000. A multigene phylogeny of the Gibberella fujikuroi species complex: Detection of additional phylogenetically distinct species. Mycoscience 41: 61-78. 
Opalski, KS, Schultheiss, H, Kogel, KH, and Hückelhoven, R. 2005. The receptor-like MLO protein and the RAC/ROP family G-protein RACB modulate actin reorganization in barley attacked by the biotrophic powdery mildew fungus Blumeria graminis f. sp. hordei. The Plant Journal 41: 291-303.

Pintye, A, Ropars, J, Harvey, N, Shin, H-D, Leyronas, C, Nicot, PC, Giraud, T, and Kiss, L. 2015. Host phenology and geography as drivers of differentiation in generalist fungal mycoparasites. PloS one 10: e0120703.

Pirondi, A, Vela-Corcía, D, Dondini, L, Brunelli, A, Pérez-García, A, and Collina, M. 2015. Genetic diversity analysis of the cucurbit powdery mildew fungus Podosphaera xanthii suggests a clonal population structure. Fungal Biology 119: 791-801.

Poland, J, and Clement, EJ. 2009. Vegetative key to the British Flora. Botanical Society of the British Isles, 2009.

Prieto, M, and Wedin, M. 2016. Phylogeny, taxonomy and diversification events in the Caliciaceae. Fungal Diversity: 1-18.

Raja, H, Schoch, CL, Hustad, V, Shearer, C, and Miller, A. 2011. Testing the phylogenetic utility of MCM7 in the Ascomycota. MycoKeys 1: 63.

Rambaut, A, Suchard, MA, Xie, D, and Drummond, AJ. 2015. Tracer v1. 6. 2014.

Reeb, V, Lutzoni, F, and Roux, C. 2004. Contribution of RPB2 to multilocus phylogenetic studies of the euascomycetes (Pezizomycotina, Fungi) with special emphasis on the lichen-forming Acarosporaceae and evolution of polyspory. Mol Phylogenet Evol 32: 1036-1060.

Reece, KS, McElroy, D, and Wu, R. 1992. Function and evolution of actins. In Evolutionary biology, Springer: 1-34.

Roberts, DM, Lukas, TJ, Watterson, DM, and Roux, SJ. 1986. Structure, function, and mechanism of action of calmodulin. Critical reviews in plant sciences 4: 311-339. 
Roger, AJ, Sandblom, O, Doolittle, WF, and Philippe, H. 1999. An evaluation of elongation factor 1 alpha as a phylogenetic marker for eukaryotes. Molecular Biology and Evolution 16: 218-233.

Romeo, O, Scordino, F, and Criseo, G. 2011. New insight into molecular phylogeny and epidemiology of Sporothrix schenckii species complex based on calmodulin-encoding gene analysis of Italian isolates. Mycopathologia 172: 179-186.

Ronquist, F, and Huelsenbeck, JP. 2003. MrBayes 3: Bayesian phylogenetic inference under mixed models. Bioinformatics 19: 1572-1574.

Sadowska-Deś, AD, Bálint, M, Otte, J, and Schmitt, I. 2013. Assessing intraspecific diversity in a lichen-forming fungus and its green algal symbiont: Evaluation of eight molecular markers. Fungal Ecology 6: 141-151.

Samson, RA, Visagie, CM, Houbraken, J, Hong, S-B, Hubka, V, Klaassen, CH, Perrone, G, Seifert, KA, Susca, A, and Tanney, JB. 2014. Phylogeny, identification and nomenclature of the genus Aspergillus. Studies in Mycology 78: 141-173.

Sang, T. 2002. Utility of low-copy nuclear gene sequences in plant phylogenetics. Critical Reviews in Biochemistry and Molecular Biology 37: 121-147.

Schmitt, I, Crespo, A, Divakar, P, Fankhauser, J, Herman-Sackett, E, Kalb, K, Nelsen, M, Nelson, N, Rivas-Plata, E, and Shimp, A. 2009. New primers for promising single-copy genes in fungal phylogenetics and systematics. Persoonia 23: 35 .

Schoch, CL, Seifert, KA, Huhndorf, S, Robert, V, Spouge, JL, Levesque, CA, Chen, W, Bolchacova, E, Voigt, K, and Crous, PW. 2012. Nuclear ribosomal internal transcribed spacer (ITS) region as a universal DNA barcode marker for Fungi. Proceedings of the National Academy of Sciences 109: 6241-6246. 
Seehausen, O, Koetsier, E, Schneider, MV, Chapman, LJ, Chapman, CA, Knight, ME, Turner, GF, van Alphen, JJ, and Bills, R. 2003. Nuclear markers reveal unexpected genetic variation and a CongoleseNilotic origin of the Lake Victoria cichlid species flock. Proceedings of the Royal Society of London B: Biological Sciences 270: 129-137.

Seifert, KA, and Lévesque, CA. 2004. Phylogeny and molecular diagnosis of mycotoxigenic fungi. In Molecular Diversity and PCR-detection of Toxigenic Fusarium Species and Ochratoxigenic Fungi, Springer: $449-471$.

Small, RL, Cronn, RC, and Wendel, JF. 2004. LAS Johnson Review No. 2. Use of nuclear genes for phylogeny reconstruction in plants. Australian Systematic Botany 17: 145-170.

Spanu, PD, Abbott, JC, Amselem, J, Burgis, TA, Soanes, DM, Stüber, K, van Themaat, EVL, Brown, JK, Butcher, SA, and Gurr, SJ. 2010. Genome expansion and gene loss in powdery mildew fungi reveal tradeoffs in extreme parasitism. Science 330: 1543-1546.

Stevens, FC. 1983. Calmodulin: an introduction. Canadian journal of biochemistry and cell biology 61: 906-910.

Swofford, DL. 2003. PAUP*. Phylogenetic analysis using parsimony (* and other methods). Version 4. Takamatsu, S. 2013. Origin and evolution of the powdery mildews (Ascomycota, Erysiphales). Mycoscience 54: 75-86.

Takamatsu, S, Havrylenko, M, Wolcan, SM, Matsuda, S, and Niinomi, S. 2008a. Molecular phylogeny and evolution of the genus Neoerysiphe (Erysiphaceae, Ascomycota). Mycological Research 112: 639-649.

Takamatsu, S, Hirata, T, and Sato, Y. 1998. Phylogenetic analysis and predicted secondary structures of the rDNA internal transcribed spacers of the powdery mildew fungi (Erysiphaceae). Mycoscience 39: $441-453$. 
Takamatsu, S, Inagaki, M, Niinomi, S, Khodaparast, SA, Shin, H-D, Grigaliunaite, B, and Havrylenko, M. 2008b. Comprehensive molecular phylogenetic analysis and evolution of the genus Phyllactinia (Ascomycota : Erysiphales) and its allied genera. Mycological Research 112: 299-315.

Takamatsu, S, Ito, H, Shiroya, Y, Kiss, L, and Heluta, V. 2015. First comprehensive phylogenetic analysis of the genus Erysiphe (Erysiphales, Erysiphaceae) I. The Microsphaera lineage. Mycologia: 15-007.

Tang, S, Jiang, W, Qiu, P, Fu, X, Li, Y, Wang, L, and Liu, S. 2017. Podosphaera paracurvispora (Erysiphaceae, Ascomycota), a new powdery mildew species on Pyrus from China. Mycoscience 58: $116-120$.

Topalidou, ES, Michael. 2014. The common phylloplane fungus Leptosphaerulina australis reduces infection by the oak powdery mildew pathogen Erysiphe alphitoides. European Journal of Plant Pathology.

Topalidou, ET, and Shaw, MW. 2016. Relationships between Oak powdery mildew incidence and severity and commensal fungi. Forest Pathology 46: 104-115.

Tretter, ED, Johnson, E, Wang, Y, Kandel, P, and White, MM. 2013. Examining new phylogenetic markers to uncover the evolutionary history of early-diverging fungi: comparing MCM7, TSR1 and rRNA genes for single-and multi-gene analyses of the Kickxellomycotina. Persoonia: Molecular Phylogeny and Evolution of Fungi 30: 106.

Tretter, ED, Johnson, EM, Benny, GL, Lichtwardt, RW, Wang, Y, Kandel, P, Novak, SJ, Smith, JF, and White, MM. 2014. An eight-gene molecular phylogeny of the Kickxellomycotina, including the first phylogenetic placement of Asellariales. Mycologia 106: 912-935.

Troch, V, Audenaert, K, Wyand, RA, Haesaert, G, Höfte, M, and Brown, JK. 2014. Formae speciales of cereal powdery mildew: close or distant relatives? Molecular Plant Pathology 15: 304-314. 
Untergasser, A, Cutcutache, I, Koressaar, T, Ye, J, Faircloth, BC, Remm, M, and Rozen, SG. 2012.

Primer3-new capabilities and interfaces. Nucleic acids research 40: e115-e115.

Vela-Corcía, D, Bellón-Gómez, D, López-Ruiz, F, Torés, JA, and Pérez-García, A. 2014. The

Podosphaera fusca TUB2 gene, a molecular "Swiss Army knife" with multiple applications in powdery mildew research. Fungal Biology 118: 228-241.

Voigt, K, and Wöstemeyer, J. 2000. Reliable amplification of actin genes facilitates deep-level phylogeny. Microbiological research 155: 179-195.

Voigt, K, and Wöstemeyer, J. 2001. Phylogeny and origin of 82 zygomycetes from all 54 genera of the Mucorales and Mortierellales based on combined analysis of actin and translation elongation factor EF-1 $\alpha$ genes. Gene 270: 113-120.

Wang, L, and Zhuang, W-Y. 2007. Phylogenetic analyses of penicillia based on partial calmodulin gene sequences. Biosystems 88: 113-126.

Wang, X-z, Xu, B-y, Ping, W, Luan, F-s, Ma, H-y, and Ma, Y-y. 2013. Identification of Powdery Mildew Pathogen and Ribosomal DNA-ITS Sequence Analysis on Melon. Journal of Northeast Agricultural University (English Edition) 20: 10-18.

Weiland, JJ, and Sundsbak, JL. 2000. Differentiation and detection of sugar beet fungal pathogens using PCR amplification of actin coding sequences and the ITS region of the rRNA gene. Plant Disease 84: $475-482$.

Werle, E, Schneider, C, Renner, M, Völker, M, and Fiehn, W. 1994. Convenient single-step, one tube purification of PCR products for direct sequencing. Nucleic acids research 22: 4354.

White, TJ, Bruns, T, Lee, S, and Taylor, J. 1990. Amplification and direct sequencing of fungal ribosomal RNA genes for phylogenetics. PCR protocols: a guide to methods and applications 18: 315322. 
Wicker, T, Oberhaensli, S, Parlange, F, Buchmann, JP, Shatalina, M, Roffler, S, Ben-David, R, Doležel, J, Šimková, H, and Schulze-Lefert, P. 2013. The wheat powdery mildew genome shows the unique evolution of an obligate biotroph. Nature genetics 45: 1092-1096.

Xiao, C, Chandler, C, Price, J, Duval, J, Mertely, J, and Legard, D. 2001. Comparison of epidemics of Botrytis fruit rot and powdery mildew of strawberry in large plastic tunnel and field production systems. Plant Disease 85: 901-909.

Ye, J, Coulouris, G, Zaretskaya, I, Cutcutache, I, Rozen, S, and Madden, TL. 2012. Primer-BLAST: a tool to design target-specific primers for polymerase chain reaction. BMC bioinformatics 13: 134 .

Yun, BW, Atkinson, HA, Gaborit, C, Greenland, A, Read, ND, Pallas, JA, and Loake, GJ. 2003. Loss of actin cytoskeletal function and EDS1 activity, in combination, severely compromises non-host resistance in Arabidopsis against wheat powdery mildew. The Plant Journal 34: 768-777.

Zhang, Z, Hall, A, Perfect, E, and Gurr, SJ. 2000. Differential expression of two Blumeria graminis chitin synthase genes. Molecular Plant Pathology 1: 125-138.

\section{LEGENDS}

Figure 1: A selection of PM infected hosts collected during the powdery mildew survey: (a) unidentified PM on Monarda didyma, (b) Neoerysiphe galeopsidis on Acanthus spinosus, (c) Erysiphe pisi on Pisum sativum, (d) Podosphaera leucotricha on Malus domestica, (e) E. trifoliorum on Trifolium arvense, (f) E. aquilegiae on Aquilegia vulgaris, (g) E. berberidis on Berberis thunbergii, and (h) E. catalpae on Catalpa bignonioides.

Figure 2: $\mathrm{BI}$ using 173 sequences of the ITS region, RCFI = 0.879. Accession names include accession code, PM name, and host identity. PPs $\geq 90 \%$ are shown in blue. Green boxes denote PM tribes. 
Figure 3: Part 1 of $\mathrm{BI}$ using 151 sequences of the $\mathrm{Mcm} 7$ region, $\mathrm{RCFI}=0.974$. Accession names include sample code, PM name, and host identity. PPs $\geq 90 \%$ are shown in blue. Green boxes denote PM tribes.

Figure 4: BI using 102 sequences of the ITS and Mcm7 regions combined, RCFI $=0.972$. Accession names include accession code, PM name, and host identity. PPs $\geq 90 \%$ are shown in blue. Green boxes denote PM tribes.

\section{FOOTNOTE}

O.Ellingham@kew.org 